\author{
O.В. Саввина
}

\title{
ЭТИЧЕСКИЕ ПРОБЛЕМЫ КЛОНИРОВАНИЯ ЧЕЛОВЕКА И ЖИВОТНЫХ
}

\begin{abstract}
Аннотация. В статье анализируются два вида клонирования человека и животных: терапевтическое и репродуктивное. Опираясь на последние научные изыскания в области клонирования, автор очерчивает круг этических проблем, связанных с клонированием. В статье рассматривается единственная ныне доступная технология клонирования - перенос ядра соматической клетки. Определение клонирования с точки зрения биологии очень важно, поскольку сразу отбрасывает распространённые мифы о назначении и использовании технологии клонирования и этических проблемах, порождаемых этой технологией. Автор разделяет этические проблемы терапевтического клонирования и репродуктивного, а также клонирования людей и животных. В статье задействованы последние научные публикации в области биологических наук преимущественно зарубежных авторов. В результате делается вывод о том, что терапевтическое и репродуктивное клонирование животных, а также терапевтическое клонирование человека не несут в себе новых этических проблем, но усиливают уже имеющиеся этические и социальные проблемы, дилеммы биоэтики, такие как этика научных публикаций, моральный статус эмбрионов и плодов, доступность медицинских ресурсов для бедных слоёв населения, социальная дифрференциация, скрытое негативное влияние на экологию, здоровье человека, невозможность полностью предсказать социальные последствия внедряемой практики или технологии до её внедрения и т.д. Репродуктивное клонирование человека может породить совершенно новые этические проблемы, связанные с изменением образа жизни человека, его полового поведения и многих других фракторов общественной жизни. Автор приходит к выводу, что мы не в состоянии предсказать, сможет ли человечество справиться с этими проблемами, но, тем не менее, это не является поводом к полному запрету на репродуктивное клонирование. Ключевые слова: биоэтика, репродуктивное клонирование, терапевтическое клонирование, технология клонирования, моральный статус эмбрионов, этика научных публикаций, этика, этика научных исследований, ответственность, этические проблемы.
\end{abstract}

Abstract. The article analyses two types of cloning: therapeutic and reproductive cloning. The author describes range of ethical problems using the latest scientific research in the field of cloning. The author considers the only one existed technology of cloning today, it is a somatic cell nuclear transfer (SCNT). Defining cloning from biological point of view is very important. It discards the myths about goals of the technology, its using and ethical problems posed by cloning. The author divides ethical problems of reproductive and therapeutic cloning, cloning of humans and animals. It is concluded in the article that therapeutic cloning of humans and therapeutic and reproductive cloning of animals do not cause new ethical problems but they exacerbate the existing ones. These problems are ethics of scientific publications, moral status of embryos, economic affordability of medical services, social differentiation, latent negative effects on ecology and people's health and "slippery slop" effects. The reproductive cloning of human beings may generate new ethical problems. We can not say now if Mankind will be able to solve these problems, but it is not a reason to prohibit the reproductive cloning of human beings.

Key words: ethics of scientific pulications, moral status of embryos, SCNT technology, therapeutic cloning, reproductive cloning, bioethics, ethics, ethics of scientific research, responsibility, ethical problems.

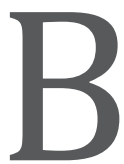

1997 г. в журнале «Nature» была опубликована статья, в которой сообщалось об успешном эксперименте по клонированию млекопитающего животного, а именно, ныне известной всем овечки Долли [1]. С тех пор, как клонирование стало реальностью, споры отно- сительно его этической допустимости не умолкают. Аргументы «за» и «против» приводятся с точки зрения религиозных конфессий, науки, медицины; в дискуссию вовлечены политики, теологи, медики, юристы и другие специалисты и слои населения, в том числе обычные граждане. 


\section{Непредсказуемое}

Несмотря на то, что клонирование с 1996 г. является реальностью, дискутирующие не всегда представляют, что такое процесс клонирования живого организма, а обыватели порой судят о клонировании, опираясь на научную фантастику. Поэтому, прежде чем перейти к этико-философским проблемам, связанным с моральной допустимостью и легализацией клонирования человека и животных, необходимо:

1) дать определение процессу клонирования, очертить возможности учёных в этой области в настоящий момент и в ближайшем будущем;

2) обозначить перспективы и возможную пользу от клонирования - а) животных, б) человека;

3) обозначить круг этических проблем, связанных с внедрением практики клонирования а) животных, б) человека.

Эти проблемы не изолированы и во многом зависят не только от возможностей учёных, но и от экономической и политической ситуации в мире, мнения и влияния религиозных лидеров, а также многих других факторов.

Прежде чем рассмотреть непосредственно процесс клонирования необходимо указать на экономическую основу этого процесса в настоящее время. Себестоимость, окупаемость, спрос и предложение на клонирование, возможность развития теневого рынка очень важно учитывать при обращении к этической проблематике. В данной статье мы будем опираться на марксистко-ленинскую теорию, согласно которой экономическая жизнь общества является базой, определяющей политическую жизнь общества [2, 3, 4]. Приблизительная оценка прибыли проектов клонирования животных и человека, определение целевой аудитории и других экономических и маркетинговых составляющих во многом позволят приблизительно очертить круг проблем, связанных с этой технологией.

Итак, определяя процесс клонирования, следует отметить, что в самом определении нет ясности. В литературе по биоэтике часто говорится о двух видах клонирования: 1) репродуктивное, целью которого является создание генетически идентичной особи; и 2) терапевтическое, цель которого - создание методов лечения, лекарственных средств. Для юриспруденции цель также является определяющим фактором, и законодательство стран тому подтверждение. Во многих странах запрещён лишь один из видов клонирования человека, как правило - репродуктивное клонирование; терапевтическое кло- нирование часто признаётся этически оправданным и юридически разрешено [5].

Возвращаясь к понятию «клонирование», заметим, что в литературе можно встретить два определения: 1) клонирование - это создание генетически идентичной особи (клеток, генов) уже существующего организма; 2) воспроизведение особи от единичного родителя $[6,7]$. Последнее определение предполагает, что организм, появившийся путём «клонирования» не обязательно генетически идентичен родителю, а также другому потомству этого же родителя [7, Chapter 4]. Создание потомства от единичного родителя хорошо известно в природе: таким образом размножаются некоторые насекомые, например, пчёлы и муравьи; но для млекопитающих этот способ совсем не свойственен. Здесь природа ушла дальше, разделив вклад в потомство между двумя родителями. Яйцеклетка млекопитающей самки (и человека в том числе) проходит целый ряд ступеней развития, чтобы стать из диплойдной клетки (содержащей полный набор хромосом) - гаплойдной клеткой (с простым - одинарным набором хромосом) [7, Chapter 4]. У человека и млекопитающих животных гаплойдны только половые клетки, при этом яйцеклетка, лишь в процессе созревания из диплойдной клетки становится зрелой яйцеклеткой (гаплойдной) со вторым полярным (направительным) тельцем [8]. Процесс созревания яйцеклетки (гаметогенез) хорошо иллюстрирует, как много природе понадобилось, образно выражаясь, времени, сил и изобретательности, чтобы преобразовать сам процесс размножения, отойдя от «клонирования», и прийти к размножению, в котором участвует два родителя. Это коренным образом поменяло не только биологию двуполых животных, но и изменило их поведение (есть даже специальный термин: «половое поведение»), их социальную и индивидуальную жизнь. Именно поэтому многих пугает идея клонирования - ведь в данном случае человек идёт против природы, применяя к млекопитающим архаический, с точки зрения биологии способ размножения, ставя под угрозу, тем самым, не только генетическое разнообразие, но и саму биологию млекопитающих, их образ жизни.

Теперь рассмотрим технологию, использованную командой Яна Вилмута при создании Долли. Этот метод называется перенос ядра соматической клетки (somatic cell nuclear transfer - SCNT). Из соматической клетки животного - донора, служащего прототипом для клона, извлекается ядро, в тоже 
время из яйцеклетки в лабораторных условиях (in vitro) другого животного «вырезается» ядро и вместо него вставляется ядро соматической клетки донора. Этот процесс сопровождается обработкой переменным и постоянным током, а иногда - химическими веществами, для того, чтобы ядро «прижилось» на новом месте и клетка могла дать развитие новому организму (стала тотипотентной) [1]. При этом эффективность технологии в 1996 г. составила лишь 0,4 \%, то есть в 99,6 \% случаев попытка переноса ядра была безуспешна или заканчивалась смертью эмбриона. Сейчас эффективность SCNT гораздо выше и в ряде случаев доходит до $20 \%$ [7, Chapter 5]. И тем не менее, 20 \% даже сейчас - большая редкость, а процент успешных SCNT животных уже давно не получается увеличить, что делает эту процедуру совсем не дешёвой. В Японии с конца 90-х годов прошлого века до 2008 г. процент успешных SCNT скота оставался практически стабильным и составлял в среднем 4,3 \% [9].

Говоря о генетической идентичности клонированного животного, не следует забывать о том, что клон не совсем генетически идентичен донору и первое из упомянутых выше определений клонирования не вполне применимо к реальным клонам. Ядерная ДНК клона такая же, как и у донора, а вот митохондриальная ДНК останется идентичной яйцеклетке, из которой удалили ядро при проведении SCNT [10]. Митохондриальная ДНК составляет 0,1 \% всего генетического материала клона. Много это или мало, довольно сложно судить, и зависит от параметров, по которым идёт оценка «весомости» вклада митондриальной ДНК. Например, мутации, происходящие в митохондриальной ДНК, могут влиять на процессы старения [7]. С точки зрения интересующей нас этической проблематики, эта особенность технологии вызывает целый ряд этических проблем. В настоящий момент учёными используется SCNT для создания клонов животных исчезающих видов с использованием эмбрионов животных других видов. Получается, что учёные создают химеру, ДНК которой одновременно принадлежит к двум видам животных. Во-первых, полностью неизвестно, как это отразится на здоровье животных, их способности к размножению и их потомстве. Во-вторых, непонятен статус подобного животного: можно ли с уверенностью определить вид подобного клона? Будет ли клонированное животное относиться к исчезающим видам? Является ли создание клона решением проблемы вымирающего вида? И, наконец, можно ли охотиться на кло- нированное животное (убийство животного, занесённого в красную книгу, как правило, запрещено)? Если указанные выше вопросы возможно решить, грамотно и аккуратно подойдя к протоколированию экспериментов и созданию законодательного регулирования подобных практик, то решить более глобальные вопросы уже сложнее. Например, изменение экосистемы в результате разведения клонированных животных, последствия применения в пищу мяса клонированных животных и т.д. Справедливости ради следует заметить, что пока что употреблять в пищу мясо потомков клонированных животных и рыб разрешено и побочных эффектов этой практики пока не выявлено.

Tем не менее, технология SCNT несёт в себе не только проблемы и высокие экономические издержки, но и массу достоинств. Сейчас клонирование животных находит применение в фармакологии и фармакогенетике. SCNT позволяет получать животных, преимущественно крупный рогатый скот, в молоке которых содержится белок, необходимый для лечения тех или иных заболеваний. C той же целью используются куры: яйца, которые несут генномодифицированные клонированные птицы, содержат белки, необходимые для создания лекарственных средств [6]. Таким образом, SCNT вносит вклад в медицину. Из изложенного выше можно сделать вывод, что подобный метод лечения отнюдь не дёшев, ведь вероятность успешной процедуры SCNT, в результате которой рождается живое животное и доживает до репродуктивного возраста, не велика. С другой стороны, клонированное животное может давать здоровое потомство, также способное давать «лечебное» молоко. К тому же вполне вероятно, что через несколько лет учёные найдут способ удешевить технологию. В тоже время стоит учитывать, что даже удешевление технологии не гарантирует того, что лекарственные средства, полученные с помощью клонированных животных, станут более доступными. Реклама, патент, франшиза, транспортировка, а также множество других факторов влияют на стоимость лекарственных средств. Кроме того, не стоит недооценивать такие явления как монополии, когда единственный производитель может диктовать цену; эмбарго и другие экономические санкции против отдельных стран, особенности экспорта и импорта товаров и услуг. В современном мире важно учитывать PR-технологии и чёрные PR-компании - производители альтернативных лекарственных средств могут разнести слухи о 


\section{Непредсказуемое}

вреде генномодифицированных продуктов, бешенстве и других опасных заболеваниях среди клонированных животных и т.д. Также увеличение процента клонированных животных и распространение нового метода лечения связанно с рисками: популяцию «лечебных» животных может поразить болезнь, а в силу слабого генетического разнообразия вымирание может наступить очень быстро и многие люди останутся без лечения. Молоко поражённых болезнью животных теоретически может заразить и организм человека. Как бы то ни было, внедрение новой практики в медицинское обслуживание всегда несёт в себе определённые риски (ярким примером может послужить «талидамидова катастрофа»), и это не повод отказываться от разработки новых методов лечения, но при этом не стоит забывать и про риски. Несмотря на возможные сложности, которые сейчас невозможно предсказать, создание новых методов лечения и развитие медицинских технологий являются, в целом, благом для человечества.

В тоже время сейчас распространяется использование клонированных генномодифицированных организмов в сельском хозяйстве и пищевой индустрии. Здесь опять присутствует две стороны медали: выращивание ГМО позволяет увеличить урожай за счёт более крупных плодов или большей урожайности модифицированной культуры, защитить растения от вредителей, а с другой стороны нельзя с уверенностью сказать, что генномодифицированные организмы безопасны для употребления в пищу. Учёные, в настоящий момент не могут провести исследования, иллюстрирующие, как отражается употребление ГМО и клонированных организмов в пищу через десять - двадцать лет, отразится ли это на втором и третьем поколении людей. Более того, провести такие исследования не представляется возможным и человечество, внедряя практику употребления ГМО и клонированных организмов, встаёт на скользкий путь. Мы не в состоянии просчитать все последствия внедрения новой практики, но если обнаружатся негативные последствия, может быть очень поздно, и мы будем не в состоянии исправить ситуацию. Примером может послужить гипотетическая ситуация, когда массовое использование клонированных генномодифицированных организмов приведет к серьёзным проблемам со здоровьем у наших потомков, скажется на их репродуктивной функции и поставит под вопрос выживание человечества.
Вторым достоинством технологии клонирования животных можно назвать создание генномодифицированных животных для экспериментов (в качестве таких животных часто используются мыши). Генная инженерия позволяет создавать мышей с генами человека, но поскольку удачные попытки генной инженерии также не отличаются высоким процентом удачных исходов, клонирование таких животных даёт возможность клонировать удачные экземпляры. Эти животные сейчас используются в экспериментах, предшествующих экспериментам с участием людей, что теоретически позволяет снизить опасность опытов для испытуемых людей. Этот же метод используется в ксенотрансплантации (пересадки органов от животных к человеку). Удачные генномодифицированные экземпляры можно клонировать и получить животных, преимущественно свиней, для операций с использованием технологий ксенотрансплантации. С одной стороны, применение клонирования животных в указанном направлении - это решение ряда медицинских вопросов, но с другой стороны, есть и альтернативные мнения. Использование животных в экспериментах, хоть и широко применяется, но, зачастую, не гарантирует безопасности людей и приносит страдания животным; а ксенотрансплантацию некоторые специалисты оценивают как самый крайний вариант в медицине, так как это направление связано с множеством рисков, а польза от него сомнительна [11].

При оценке этических проблем, связанных с клонированием животных, нужно выделить, прежде всего, те, которые менее всего подвержены аргументу slippery slop, подразумевающему, что мы не можем с большой долей вероятности заключить о результатах внедрения практики до её внедрения. Как ни банально это звучит, но к таким негативным последствиям относятся возможные результаты внедрения SCNT, которые свойственны для любых новых технологий, а именно: 1) её потенциальная скрытая опасность для потребителя; 2) опасность для экологии планеты; 3) дороговизна и недоступность новой технологии и основанных на ней методов лечения для широких слоев населения. Последнее, в данном случае, усиливает не только разницу в образе жизни элиты и основной массы населения, но делает богатых более здоровыми, а бедных - более больными. Эта тенденция существовала во все времена, но именно с приходом биотехнологий и клонирования стала особенно актуальна и имеет все шансы расти по 
экспоненте. Поэтому, на наш взгляд, при создании мер по регулированию и применению технологии клонирования животных стоит учитывать, прежде всего, именно эту проблему. Можно констатировать, что практика клонирования животных не несёт кардинально новых этических проблем, но усиливает старые, а именно - влияние техногенного фактора на экологию планеты, активное изменение человеком собственной среды обитания.

Клонирование вызывает большие опасения и недовольство со стороны довольно широких слоёв населения и особенно христианских и мусульманских конфессий, в первую очередь, как клонирование человека. Пока что не было заявлено о клонировании человека с использованием переноса ядра соматической клетки (SCNT), единственным доступным в настоящий момент методом клонирования млекопитающих. И, тем не менее, клонирование человека, судя по всему, не за горами. Совсем недавно учёным из США (май, 2013) и Южной Кореи (апрель, 2014) удалось клонировать эмбриональные клетки человека из соматических клеток $[12,13]$. В связи с этим, уже одна из этических проблем, связанных с клонированием стала реальностью, а именно - смерть эмбрионов человека и их использование в качестве терапии. Это широко обсуждаемая проблема не связана напрямую с клонированием человека: вопрос о моральном статусе эмбрионов и плодов был поднят ещё до рождения первого ребёнка, появившегося на свет при помощи экстракорпорального оплодотворения в 1978 г., когда учёные лишь начинали проводить эксперименты с участием эмбрионов человека. В настоящий момент существуют документы международных организаций, национальные законодательства, в которых закреплён статус эмбрионов и плодов, и появление клонирования эмбрионов человека не открывает новой проблемы, но, в некотором роде, вновь обращает наше внимание на уже существующую проблемную область в биоэтике. Исследования с участием эмбрионов человека давно стали рутинными, а не из ряда вон выходящими. Даже среди приверженцев Римской католической церкви, одной из самых нетерпимых конфессий по отношению к исследованиям с участием эмбрионов человека, нет единого мнения относительно этого вопроса; а некоторые католики-теологи говорят об этической оправданности подобного рода экспериментов [14]. Возвращаясь к двум типам клонирования человека: терапевтическому и репродуктивному, заметим, что проблемы тера- певтического клонирования сводятся преимущественно к вопросу о моральном статусе эмбрионов и плодов, который уже давно считается самостоятельным вопросом биоэтики; и логичнее было бы рассматривать терапевтическое клонирование именно в контексте этого вопроса, а не наоборот.

Как ни странно, но клонирование человека сильно обострило этические проблемы, которые лишь косвенно связанны с клонированием. B 2004 г. южно-корейский учёный Вонг (Woo Suk Hwang) заявил о клонировании эмбриона человека [15]. Новость стала сенсацией, а Вонг - знаменитостью; но через год выяснилось, что исследование научного коллектива Вонга оказалось фальсификацией [16]. С тех пор в научные круги периодически проникали слухи об успешном клонировании эмбриона или клеток человека, но научное сообщество относилось к таким заявлениям с большим подозрением [17; 18]. Некоторые учёные, желая славы, фальсифицировали данные или делали преждевременные выводы, таким образом, попытки клонировать человека ударили по научной этике и этике научных публикаций, и без того чрезвычайно проблемной области. Не сложно заметить, что даже терапевтическое клонирование не несёт в себе новых этических проблем. Оно усиливает существующие проблемы, как бы заставляя нас обратить внимание на этически проблемные зоны. Терапевтическое клонирование, тем самым, является катализатором назревших противоречий, требующих своего решения. Это лишнее напоминание миру о необходимости измениться.

Наконец, мы подошли к этическим проблемам, связанным с репродуктивным клонированием человека. Сейчас в большинстве стран запрещен этот тип клонирования. Чтобы осознать, какие этические проблемы несёт репродуктивное клонирование человека, достаточно взглянуть на проблемы, связанные с репродуктивным клонированием животных. В первую очередь, это риск патологий: клонированные животные часто страдают от различных заболеваний, их иммунитет снижен по сравнению с сородичами, возникшими естественным путём, органы клонированных животных часто увеличены [19]. Клонирование также используется при воссоздании исчезающих животных, и высказываются идея клонирования вымерших видов. Параллельно появляются идеи клонировать наших предков: неандертальцев и другие виды homo [7]. Каким же статусом будут обладать вымершие виды homo при успешной попытке такого 


\section{Непредсказуемое}

научного проекта? К счастью, всерьёз задумываться над этим вопросом пока нет необходимости: по утверждению Шухрата Миталипова, научный коллектив которого впервые клонировал эмбрион человека в 2013 г., клонирование даже обычного ребёнка homo sapiens сейчас технически невозможно. Миталипов провёл сотни попыток по клонированию обезьяны, и самая удачная из этих попыток закончилась замершей беременностью на сроке два месяца [13].

Ещё один важный вопрос, связанный с репродуктивным клонированием, волнующий участников биоэтического дискурса - статус клона человека. Будет ли он обладать правами, идентичными нашим? Распространяется ли на клонов человека понятие прав человека? Кто будет ответственным, если в результате клонирования родившийся ребёнок будет иметь патологии развития? Каковы должны быть отношения донора и клона, считать ли их родителем и ребёнком, или братьями, сёстрами, возможно, чужими людьми? Кроме того, возникает большой соблазн использовать клонированных людей, руководствуясь утилитарными принципами, и обосновывая вред, приносимый этим людям, а также жестокость по отношению к ним, насильственную эвтаназию благом для общества. Подумать только, сколько можно провести научных экспериментов, если заранее лишить «клонов» человеческих прав. Поэтому, возможность клонирования людей «соблазняет» учёных откровенным фашизмом, когда мы вводим критерий «второсортности» человека, и не важно, что является этим критерием - раса или способ рождения. Справедливости ради, следует заметить, что «фашизм» по отношению к клонам человека маловероятен в современном обществе. А астрономическая сумма, которая потребуется, по меньшей мере, на первых стадиях развития технологии репродуктивного клонирования, предотвратит развитие теневого рынка.

И, тем не менее, есть основания полагать, что право, родственные отношения, семья, имущественные отношения, социализация человека, и многие другие устоявшиеся практики общественной жизни и жизни индивида, непременно подвергнуться деформации и трансформации в результате появления клонирования человека, возникнет целый ряд новых этических проблем, о которых мы сейчас можем только догадываться. Как уже было отмечено выше, наша биология и психология, наш социум, общественная мораль, семья формировались тысячелетиями и базиро- вались на естественном для человека двуполом способе размножения. Наша биологическая, психологическая и социальная природа подразумевает именно такой способ размножения. Вводя новую практику - клонирование человека, само человечество напоминает ребёнка, играющего с огнём. Мы изменяем собственную природу, вводя альтернативный способ размножения. Тяжело сказать, как скажется эта практика на поведении и психологии человека, социальных отношениях, тем не менее, ориентируясь на уже имеющийся опыт человечества по внедрению вспомогательных репродуктивных технологий, можно сделать приблизительный прогноз. Сразу следует отметить, что эффект внедрения репродуктивного клонирования человека будет двояким и приведёт как положительным, так и отрицательным результатам, поскольку потенциальная сфера применения технологии SCNT весьма обширна. Рассмотрим, в первую очередь, потенциальную выгоду для человечества от SCNT человека (или другого, ещё не разработанного метода клонирования).

Как утверждают сторонники репродуктивного клонирования, оно несёт в себе не только опасности, но и решения ряда проблем. Клонирование даст возможность лесбиянкам иметь своего ребёнка - когда обе женщины вносят генетический вклад в ребёнка. Это возможно, если в качестве донора выступает одна из партнёрш, тогда ребёнок будет нести её ядерную ДНК, а вторая женщина предоставит яйцеклетку, в таком случае ребёнку достанется митохондриальная ДНК «второй мамы». С точки зрения либерализма - это хорошо, так как даёт возможность альтернативным семьям иметь генетически своего ребенка, что, возможно, сделает отношения в такой семье более тёплыми. С другой стороны, подобный способ решения проблемы позволит женщинам размножаться без участия мужчин. Следствия такой возможности могут быть очень печальными. Вот лишь некоторые сценарии подобной практики.

Сценарий 1. Некоторые радикально настроенные феминистки образуют закрытую колонию, где разжигают в подрастающем поколении девочек ненависть к мужчинам. Они становятся опасны для привычного «двуполого» общества, расценивая мужчин как порождение зла, а женщин, живущих с ними - как предателей. В знак протеста против «власти мужчин» они проводят ряд террористических атак. Не стоит и говорить, что свободный выбор образа жизни в таком коллективе невозможен. 
Сценарий 2. Семьи лесбиянок становятся распространённым явлением, а услуга клонирования ребенка для нетрадиционных пар - распространённой медицинской услугой. Религиозные фанатики видят в таких семьях угрозу традиционным устоям и начинают угрожать альтернативным семьям физической расправой, постепенно переходя от слов к действиям, взрывают медицинские клиники, предоставляющие услуги SCNT человека.

Сценарий 3. Самый, пожалуй, негативный вариант развития событий проиллюстрирован в фильме «Секс-миссия или новые амазонки» польского режиссера Юлиуша Махульского. В этом фильме показывается общество, состоящее из одних женщин. Когда же археологи нашли мужчин, подвергшихся замораживанию более чем пятьдесят лет назад, после их «разморозки» правительство мира «новых амазонок» принимает решение об их «натурализации» - операции по смене пола. В фильме всё заканчивается благополучно, но в реальности, если похожие условия будут созданы, вряд ли двое мужчин смогут изменить мир женщин, родившихся и выросших без мужчин.

Ещё одним плюсом технологии SCNT является возможность клонировать тяжело больного, или умершего родственника. Но, во-первых, это не будет тот же самый человек даже генетически, ведь митохондриальная ДНК клона почившего родственника будет ДНК донорской яйцеклетки. Даже если взять яйцеклетку от той же женщины, которая родила «оригинал», что далеко не всегда возможно, клон всё равно вырастит другим, так как человек, его индивидуальность и личность во многом зависят от среды обитания, условий, в которых растёт человек, а повторить эти условия невозможно. Кроме того, от клона могут ждать тех же интересов, того же поведения, профессиональных и личных пристрастий, которые были присущи донору-оригиналу, а ведь клон способен выбрать свой путь, заводить другие знакомства, выбирать новые хобби и занятия. И что будет с родственниками, клонировавшими ребенка, которые внезапно осознали, что это не тот же человек, который был им так близок? Как будут складываться отношения в семье и какие новые комплексы и неврозы могут получиться в результате внедрения технологии репродуктивного клонирования в семейные отношения? Все эти факторы делают технологию репродуктивного клонирования очень сомнительным решением проблемы. К тому попытка клонировать умершего - это попытка изменить прошлое, отмо- тать время назад, тогда как жизнь всегда требует двигаться вперёд. «Зацикливание» на прошлом опыте ведёт к появлению стереотипа поведения, который человек использует в будущем по поводу и без, что, в свою очередь, порождает внутренние конфликты, которые выливаются в неврозы и непоследовательное поведение [20]. Карен Хорни в своей известной работе «Наши внутренние конфликты. Конструктивная теория невроза» называет причиной невроза базисный конфликт, который сформировался в прошлом под действием ситуации или ряда похожих ситуаций, сильно повлиявших на человека. Без сомнения, смерть близкого человека - большой стресс для большинства людей, когда свершившийся факт тяжело осознать и принять, попытаться жить и развиваться дальше. Согласно Хорни, сам индивид, как правило, не признаёт наличия невроза или внутреннего конфликта, поэтому не всегда обращается за помощью к специалисту, думая, что причины его невзгод кроются во внешнем мире. Клонирование умершего родственника или любимого - это тоже попытка повлиять на внешний мир, изменить прошлое, когда душевная травма, полученная в прошлом, находится внутри и приносит страдания. Часто подобные неврозы сопровождаются непоследовательностью в поведении: «Мать, сверх меры заботящаяся о своих детях, забывает дни их рождения. Человек, всегда щедрый по отношению к другим, боится потратить немного денег на самого себя. Другой человек, страстно жаждущий одиночества, ухитряется никогда не быть одиноким. Третий, снисходительный и терпимый к большей части других людей, чрезмерно строг и требователен по отношению к самому себе» [20, гл. 2]. Учитывая то, что клонирование не исключает стадию детства, клону придётся расти вместе с душевной травмой своего воспитателя, испытывая на себе противоречия в поведении и мировоззрении своего «родителя». Таким образом, практика клонирования умерших близких людей может сформировать некий «синдром клона», когда человек воспитывается одним или несколькими родителями, не пережившими и не принявшими ситуацию в прошлом, по сути, не имеющий настоящих родителей, но имеющий перед собой тень «оригинала», пусть и не идеального, к которому ему следует стремиться. Можно ли вырасти психически здоровым в подобных условиях? Возможно, но это будет на порядок сложнее, чем обычному ребёнку.

Негативные проявления практики репродуктивного клонирования, по меньшей мере, его масштабы, 


\section{Непредсказуемое}

можно приблизительно предсказать, опираясь на историю развития вспомогательных репродуктивных технологий. Появление экстракорпорального оплодотворения породило ряд проблем, таких как ответственность за неудачную процедуру ЭКО, доступность процедуры с экономической точки зрения, забор донорских яйцеклеток и вред для здоровья доноров яйцеклеток, возникновение и регулирование рынка половых гамет. Практика суррогатного материнства к уже существующим проблемам добавила появление детей без гражданства (когда из страны, в которой разрешено суррогатное материнство, генетические родители не могут вывезти ребёнка в родную страну, в которой суррогатное материнство запрещено), споры из-за детей между генетическими и суррогатными родителями, ненужные дети как для генетических, так и для суррогатных родителей, белые пятна в законодательствах, регулирующих суррогатное материнство и большое количество судебных разбирательств, проблемы со здоровьем у детей, появившихся на свет благодаря новой технологии, и вред для здоровья, приносимый суррогатным матерям [21]. А ведь суррогатное материнство гораздо ближе к нашей природе, чем репродуктивное клонирование, что косвенно свидетельствует о том, что наше общество ещё не вполне готово к появлению новой технологии. С другой стороны, появление процедуры ЭКО позволило многим людям, которые не могли иметь детей стать родителями, а суррогатное материнство - расширило этот круг. Кроме того, для многих суррогатных матерей это очень весомый доход, и многие женщины не раз ставились суррогатными матерями. В некоторых клиниках даже предоставляют место для проживания, правильное и полноценное питание, компьютерные и другие курсы для суррогатных матерей [21]. Так что для некоторых женщин суррогатное материнство - способ многое узнать, и возможно, получить новую профессию.

Подводя итог, заметим, что терапевтическое клонирование человека не несёт в себе новых этических проблем, но весомо усиливает уже существующие проблемы: моральный статус эмбрионов человека, опасность побочных эффектов для пациентов при внедрении новой медицинской технологии, усугубление социального расслоения и доступ к здравоохранению небогатых слоев населения, этика научных публикаций. Репродуктивное клонирование животных также грозит усилением имеющихся проблем и созданием новых факторов, влияющих на окружающую среду и экологию планеты, влияние которых мы не всегда способны предсказать. С другой стороны, легализация репродуктивного клонирования человека в настоящий момент, если бы эта технология была доступна, в значительной степени деформировала или трансформировала бы многие сферы нашей жизни, создала бы массу этических, социальных проблем, привела бы к новым, неизвестным ранее неврозам. И, тем не менее, это не повод ставить запрет на репродуктивном клонировании человека. Развитие технологий, и биотехнологий в частности, сложно остановить. Они изменяют сферы нашей деятельности, меняют наш опыт, порождая новые проблемы и давая новые возможности. Технология клонирования человека может стать изобретением, более значительным чем колесо или паровая машина, и это надо учитывать, прогнозируя негативные эффекты и стараясь их нивелировать путём чётких и проработанных законов, рекомендаций и целой системы комплексных мер. Задумываться о создании такой системы следует уже сейчас, поскольку ещё недавно клонирование эмбриона человека казалось мифом, а сейчас - это реальность.

\section{Список литературы:}

1. Wilmut I., Schnieke A.E., McWhir J., Kind A.J. \& Campbell K.H.S. Viable offspring derived from fetal and adult mammalian cells. Nature 385, 810-813 (27 Feb 1997).

2. Маркс К. К критике политической экономии. (URL: http://esperanto.mv.ru/Marksismo/Krit/index.html).

3. Маркс К. Капитал T. 1. (URL: http://www.esperanto.mv.ru/Marksismo/Kapital1/).

4. Плеханов Г.В. Основные вопросы марксизма. (URL: http://leninism.su/works/68-tom-29/2037-g-v-plexanov-losnovnyevoprosy-marksizmar.html).

5. Pattinson S., Caulfield T. Variations and voids: the regulation of human cloning around the world. // BMC Medical Ethics. 2004, 5:9. (DOI: 10.1186/1472-6939-5-9).

6. Steinbock B. The Oxford Handbook of Bioethics. Oxford University Press, 2007. Pp. 416-440.

7. Loike JD and Fischbach RL: Frontiers in Bioethics. New York: ST Press, 2013.

8. Гильберт С. Биология развития / Пер. с англ. М.: Мир, 1993. Т. 3. С. 613-620.

9. Watanabe S., Nagai T. Survival of embryos and calves derived from somatic cell nuclear transfer in cattle: a nationwide survey in Japan. Animal Science Journal (2011) 82, 360-365. (DOI: 10.1111/j.1740-0929.2010.00846.x).

10. Evans M.J., Gurer C, Loike J.D., Wilmut I, Schnieke A.E., Schon E.A. 1999. Mitochondrial DNA genotypes in nuclear transferderived cloned sheep. Nature Genetics 23 (1): 90-93. 


\section{Психология и психотехника 3(78) • 2015}

11. Fovargue S. Xenotransplantation and Risk: Regulating a Developing Biotechnology. Cambridge University Press, 2011. Pp. 14-16.

12. Chung Y.G. et al. Human Somatic Cell Nuclear Transfer Using Adult Cells Cell Stem Cell Volume 14, Issue 6, pp. 777-780, 5 June 2014. (DOI: http://dx.doi.org/10.1016/j.stem.2014.03.015).

13. Baker M. Stem cells made by cloning adult humans // Nature. (URL: http://www.nature.com/news/stem-cells-made-bycloning-adult-humans-1.15107).

14. Zuradski T. Moral uncertainty in bioethical argumentation: a new understanding of the pro-life view on early human embryos. Theoretical Medicine and Bioethics. December 2014, Volume 35, Issue 6, pp 441-457.

15. Hwang et al. Evidence of a Pluripotent Human Embryonic Stem Cell Line Derived from a Cloned Blastocyst // Nature. Vol. 303. № (5664): pp. 1669-1674.

16. Cyranoski D. Whistle-blower breaks his silence // Nature. Vol. 505, pp. 593-594. Published at 28 January 2014. (URL: http:// www.nature.com/news/whistle-blower-breaks-his-silence-1.14598).

17. Nickerson C. Scientists say they cloned human embryo // The Boston Globe, January 18, 2008. (URL: http://www.boston. com/news/science/articles/2008/01/18/scientists_say_they_cloned_human_embryo/?page=2).

18. Bernstain M. et al. Cloned human embryos coverage roundup // The American Journal of Bioethics. (URL: http://www. bioethics.net/2008/01/cloned-human-embryos-coverage-roundup/).

19. Chapter V. Animal Health Risks / A. Potential Hazards and Risks to Animals Involved in Cloning // Официальный сайт U.S. Foоd and Drug Administration. (URL: http://www.fda.gov/AnimalVeterinary/SafetyHealth/AnimalCloning/ucm124840.htm).

20. Хорни К. Наши внутренние конфликты. Конструктивная теория невроза. (URL: http://www.psychol-ok.ru/lib/horney/ nvk/nvk_04.html).

21. Mohapatra S. Stateless Babies \& Adoption Scams: A Bioethical Analysis of International Commercial Surrogacy. Berkeley Journal of International Law, Vol. 30, Iss. 2 [2012], Art. 4. Pp. 412-450.

\section{References (transliteration):}

1. Wilmut I., Schnieke A.E., McWhir J., Kind A.J. \& Campbell K.H.S. Viable offspring derived from fetal and adult mammalian cells. Nature 385, 810-813 (27 Feb 1997).

2. Marks K. K kritike politicheskoi ekonomii. (URL: http://esperanto.mv.ru/Marksismo/Krit/index.html).

3. Marks K. Kapital T. 1. (URL: http://www.esperanto.mv.ru/Marksismo/Kapital1/).

4. Plekhanov G.V. Osnovnye voprosy marksizma. (URL: http://leninism.su/works/68-tom-29/2037-g-v-plexanov-losnovnyevoprosy-marksizmar.html).

5. Pattinson S., Caulfield T. Variations and voids: the regulation of human cloning around the world. // BMC Medical Ethics. 2004, 5:9. (DOI: 10.1186/1472-6939-5-9).

6. Steinbock B. The Oxford Handbook of Bioethics. Oxford University Press, 2007. Pp. 416-440.

7. Loike JD and Fischbach RL: Frontiers in Bioethics. New York: ST Press, 2013.

8. Gil'bert S. Biologiya razvitiya / Per. s angl. M.: Mir, 1993. T. 3. S. 613-620.

9. Watanabe S., Nagai T. Survival of embryos and calves derived from somatic cell nuclear transfer in cattle: a nationwide survey in Japan. Animal Science Journal (2011) 82, 360-365. (DOI: 10.1111/j.1740-0929.2010.00846.x).

10. Evans M.J., Gurer C, Loike J.D., Wilmut I, Schnieke A.E., Schon E.A. 1999. Mitochondrial DNA genotypes in nuclear transferderived cloned sheep. Nature Genetics 23 (1): 90-93.

11. Fovargue S. Xenotransplantation and Risk: Regulating a Developing Biotechnology. Cambridge University Press, 2011. Pp. 14-16.

12. Chung Y.G. et al. Human Somatic Cell Nuclear Transfer Using Adult Cells Cell Stem Cell Volume 14, Issue 6, pp. 777-780, 5 June 2014. (DOI: http://dx.doi.org/10.1016/j.stem.2014.03.015).

13. Baker M. Stem cells made by cloning adult humans // Nature. (URL: http://www.nature.com/news/stem-cells-made-bycloning-adult-humans-1.15107).

14. Zuradski T. Moral uncertainty in bioethical argumentation: a new understanding of the pro-life view on early human embryos. Theoretical Medicine and Bioethics. December 2014, Volume 35, Issue 6, pp 441-457.

15. Hwang et al. Evidence of a Pluripotent Human Embryonic Stem Cell Line Derived from a Cloned Blastocyst // Nature. Vol. 303. № (5664): pp. 1669-1674.

16. Cyranoski D. Whistle-blower breaks his silence // Nature. Vol. 505, pp. 593-594. Published at 28 January 2014. (URL: http:// www.nature.com/news/whistle-blower-breaks-his-silence-1.14598).

17. Nickerson C. Scientists say they cloned human embryo // The Boston Globe, January 18, 2008. (URL: http://www.boston. com/news/science/articles/2008/01/18/scientists_say_they_cloned_human_embryo/?page=2).

18. Bernstain M. et al. Cloned human embryos coverage roundup // The American Journal of Bioethics. (URL: http://www. bioethics.net/2008/01/cloned-human-embryos-coverage-roundup/).

19. Chapter V. Animal Health Risks / A. Potential Hazards and Risks to Animals Involved in Cloning // Официальный сайт U.S. Food and Drug Administration. (URL: http://www.fda.gov/AnimalVeterinary/SafetyHealth/AnimalCloning/ucm124840.htm).

20. Khorni K. Nashi vnutrennie konflikty. Konstruktivnaya teoriya nevroza. (URL: http://www.psychol-ok.ru/lib/horney/nvk/ nvk_04.html).

21. Mohapatra S. Stateless Babies \& Adoption Scams: A Bioethical Analysis of International Commercial Surrogacy. Berkeley Journal of International Law, Vol. 30, Iss. 2 [2012], Art. 4. Pp. 412-450. 